31 Brohan E, Elgie R, Sartorius N, Thornicroft G. Self-stigma, empowerment and perceived discrimination among people with schizophrenia in 14 European countries: the GAMIAN-Europe study. Schizophr Res 2010; 122: 232-8.

32 Thornicroft G. Most people with mental illness are not treated. Lancet 2007 370: $807-8$.

33 Thornicroft G, Rose D, Kassam A. Discrimination in health care against people with mental illness. Int Rev Psychiatry 2007; 19: 113-22.

34 Corrigan PW, Watson AC, Barr L. The self-stigma of mental illness: implications for self-esteem and self-efficacy. J Soc Clin Psychol 2006; 25: 875-84
35 Birchwood M, Trower P, Brunet K, Gilbert P, Iqbal Z, Jackson C. Social anxiety and the shame of psychosis: a study in first episode psychosis. Behav Res Ther 2007; 45: 1025-37.

36 Livingston JD, Boyd JE. Correlates and consequences of internalized stigma for people living with mental illness: a systematic review and meta-analysis. Soc Sci Med 2010; 71: 2150-61.

37 Byrne R, Morrison AP. Young people at risk of psychosis: their subjective experiences of monitoring and cognitive behaviour therapy in the EDIE 2 trial. Psychol Psychother, in press.

38 International Early Psychosis Association Writing Group. International clinical practice guidelines for early psychosis. Br J Psychiatry 2005; 187 (suppl 48): s120-4.

\section{poems \\ by doctors}

... and thus it came to pass...

Inanimate mechanical forces

Rampage through the central nervous systems

of once beautiful people

Distorting affects and salience

To such an extent

That intentional self-harm by exposure to organic solvents, hot vapours, wood preservatives

Or firearm discharge

Take place

Whether in private homes

Public administrative areas

Or institutional places of residence 